\title{
Discussion Theater. A Method of Democratic Education
}

\author{
Georg Lind \\ (Universität Konstanz; Georg.Lind@uni-konstanz.de)
}

\begin{abstract}
„As surely as visual representation is more powerful than dead letters or cold narration, it is equally certain that the stage wields a more profound and more lasting influence than morality or law."

Friedrich Schiller, The Stage Considered as a Moral Institution (1784).
\end{abstract}

„The self-dependence with which [the public] acts excludes every outside influ ence; and it is not in so far as [the presentation] helps reflection (which con ᄀtains an obvious contradiction), but only in so far as it creates freedom for the intellectual faculties..."

Friedrich Schiller, On the Aesthetic Education of Man (1793-95).

\section{The Democratic Paradox}

The greatest threat to democracy, it seems, comes from democracy itself: it can destroy itself. The constitution and the laws are powerless in the face of this paradox. The success of politicians inimical to democracy at the polls here and in other countries shows that the threat is real. If we restrict our endeavors to sustain democracy merely to demands for structural change and leave people out of account democracy can turn into dictatorship.

We all live in a state of ambivalence. On the one hand we desire more democracy, but, on the other, the demands made upon us by living together in a democracy are often too great and can give rise to fear. Living in a democracy means that people must deal with and attempt to solve problems and conflicts on their own and cannot leave this process to others. This often involves exhausting disputes with people who think differently.

In the hope of finding relief from the strain of such disputes we often wish for stricter laws. However, with every law that is passed we restrict the freedom and equality we actually desire. We already have more laws than we know and can follow and more than the legal system can enforce on all people. Increases in legislation also lead to more inequality than a democracy can bear in the long term. Whereas freedom has diminished for the average citizen, rich citizens can often even expand the scope of their freedom 
with the help of expensive lawyers.

However, even if we had perfect laws and perfect morality these could not protect us from the need to deal with problems and conflicts. This had to be acknowledged by a group of training officers I worked with on a program commissioned by the Inspector General of the German Armed Forces, which was designed to promote the capacity of soldiers for reflection and discussion. The officers at first expressed doubts about the necessity of such training, as, in their opinion, the decisions of the soldiers were determined solely by the requirements of command and obedience. When I told them the story of a soldier who had to make a difficult decision and asked them whether he had taken the right decision the categories of command and obedience where of no help to them. They immediately began to discuss vehemently.

After making this experience they were highly motivated to learn how to promote the capacity for reflection and discussion.

\section{Lacking Moral Competence}

Criminality and anti-democratic movements are not an expression of a disposition towards evil, as it is sometimes asserted, but signalize a lack of moral and democratic competence (briefly termed moral competence, Lind 1998). We know today that people who lack this ability can usually only solve problems or conflicts by resorting to violence or deceit or by subjecting themselves to the leadership of others.

Moral competence is not a "hypothetical construct” ascertained non-transparently by means of arbitrary statistical procedures. It is, rather, a genuine ability, which is openly revealed in people's behavior. It can, for example, be readily recognized by the way people react to arguments in a discussion (Lind 2015). People who lack moral competence cannot distinguish between opinions and arguments. Consequently they have no understanding for the task of evaluating arguments for or against a point of view, after they have expressed their own opinion. „Why should I repeat myself”, one participant in such a test protested. When their moral competence begins to emerge, they tackle the task, but fail to understand that arguments are meant to help them test the validity of their own opinions (rationality); they only use the arguments to defend their original opinion (rationalization). As a result they indiscriminately accept all arguments that support their decision and no less indiscriminately reject opposing arguments. It is only at a certain level of moral competence that people recognize that arguments are a means of testing and, if need be, rethinking the correctness of decisions on the basis of moral orientation. Their growing competence is revealed when they no longer only judge arguments by the degree of conformity with their own opinions, but also in terms of their moral quality. Only at this point in their development are people in a position to reflect on problems and conflicts on the basis of moral criteria. And only now are they able to reach a consensus with other people without resorting to violence or deceit or without 
being forced by others to accept a consensus. This is an indispensable precondition for democratic opinion formation and even for democracy itself. It is therefore important that all people have the opportunity to develop a minimum of moral competence.

The consequences of a lack of moral competence can be limited by more police control but they cannot be overcome in this way. It is not possible to place a watchdog alongside each individual in order to prevent them from behaving in a criminal way or forcing them to behave cooperatively. This would not only overstrain the financial possibilities a society has but also its moral resources. As Immanuel Kant pointed out (1784), policemen, lawyers, government officials and legislators also need to be controlled. „Man is an animal which... requires a master... But whence does he get this master? Only from the human race. But then the master is himself an animal and needs a master."

The findings of many empirical studies, including experiments, leave scarcely any room for doubt about the causal significance of moral competence for peaceful coexistence without violence and deceit (for sources see Kohlberg \& Candee 1984; Lind 2015). A lack of moral competence leads people to practice deceit in examination situations and to cover up their own and other people's violations of rules, not to report observed breaches of a rule, to quickly lose their trust in a cooperation partner, to ignore agreed arrangements, to follow immoral orders of authorities (Milgram Experiment), to take drugs when they are in difficult circumstances, to refuse to help people in need, to take too much time and energy when making simple decisions, to disturb lessons and to show low learning performance.

Lack of moral competence is possibly also responsible for the very high correlation between economic inequality in a society and poverty, disease, criminality, mistrust of others, xenophobia and other scourges of mankind (Wilkinson \& Prickett 2010). Excessive striving for wealth at the expense of others and of nature seems to be a consequence of the inability to solve conflicts and problems on the basis of law and morality. When the wealth sought for by far exceeds what is needed for an agreeable life wealth seems to have become an end in itself. People then need it for its own sake, in order to protect themselves from the consequences of their own actions, for example when they buy islands as places of residence, turn their property into fortifications, acquire houses in „safe” countries, hire personal bodyguards, employ expensive lawyers or make donations to political parties. Recently, for example, the chief executive of a big company frankly justified his income of 10 million euros a year by pointing out that he was always living „with one foot in prison”.

\section{Education Is Imperative}

For democracy to work effectively people must be enabled to solve problems and conflicts for themselves by reflection and discussion on the basis of moral principles 
instead of resorting to violence or deceit or abandoning their freedom and subjecting themselves to a leader. Democracy needs education. "Educate, then, at any rate, for the age of implicit self-sacrifice and instinctive virtues is already flitting far away from us, and the time is fast approaching when freedom, public peace and social order itself will not be able to exist without education." This is the conclusion drawn by Alexis de Tocqueville (Democracy in America 1835), who, in the 1830s, intensively studied the then young US American democracy. Thomas Jefferson (1940), the author of the American Declaration of Independence, also adopts the same position. If we believe that the citizens are not mature enough for democracy, he repeatedly wrote, then we should not take democracy from them, but must promote their maturity through education. The founders of American democracy thus placed the greatest value on the education of all citizens. This led, at an early stage, to the introduction of obligatory general education, community schools and freedom from school fees. In Germany, too, it was recognized after the two world wars that the newly acquired democracy could only be sustained if all citizens were given the opportunity to enjoy a democratic education.

However, this insight has been increasingly losing nowadays. When people talk today of education the maintenance of democracy and the mediation of the competence needed for its preservation are scarcely ever in the foreground. They are concerned instead with its usefulness for the individual. In order to guarantee this, young people are subjected to a close-meshed barrage of grading, examinations and comparison tests. This reglementation by means of externally defined performance standards massively restricts the opportunities for the acquisition and practice of the competence needed for reflection and discourse. In particular, the control of individual learning success and the teaching effects of education under time pressure by means of comparison tests accompanied by penalties obstructs the development of reflective and discursive competence. Such tests are only rewarded when the candidate reproduces the „right” answer quickly and uncritically without reflecting on the questions. This kind of education helps to create uncritical subjects and not citizens with moral competence. The fact that moral competence is also an important precondition for sustainable success in the economy is often overlooked in this context (Wilkinson and Pickett 2010).

\section{The Promotion of Moral Competence: A Neglected Issue}

Education is important, but education in the classical sense alone is not enough to sustain democracy. Democracy calls for a purposeful promotion of the moral and democratic competence of all citizens. If we want people to accept personal responsibility for their actions and to participate in democratic opinion formation, we must help them to develop above all the ability to talk and to listen, to express their needs and convictions in words and to understand the needs and convictions of others. Where words fail violence 
and deceit rule.

Appeals to uphold democratic ideals are easy to make, but unnecessary and arrogant. The wish for freedom and democracy stems from people themselves and must not be communicated to them by politicians and teachers. Appeals to participate more in political life are largely ineffective. People would like to participate more but often they lack not only the time but also the ability to express their ideas and opinions and to exchange arguments with others without falling out with them.

It makes sense to provide young people with theoretical knowledge of democratic institutions, with the wording of the constitution, the institutions that exist and the way the political system functions (on paper). But we must be aware that the knowledge of facts alone is not enough to enable active participation in a democratic society.

It also makes sense to enable people to participate in democratic living together, for example by means of social training programs (such as „Service Learning”), political projects (such as „Living and Learning Democracy”) or participatory theater (such as Augusto Boal's „Theater of the Oppressed”). Most of the participants find such activities informative and entertaining. But it is neither probable nor scientifically proven that they promote democratic competence. Furthermore, such projects often attract only people who are „predisposed” to join them. Even the Just Community Schools of Kohlberg and his colleagues had no promotional effects. (Lind 2015). When we tested this approach in North Rhine Westphalia in the 1980s in the framework of the project „Demokratie und Erziehung in the Schule" (DES) [Democracy and Education in Schools"] the results were in fact positive. The DES project was not only successful in the eyes of the students, teachers, school directors and parents; the test also revealed that the moral competence of the students increased (Lind \& Raschert 1987; Lind \& Althof 1992; Lind 2002; Henk in Lind 2016, $121 \mathrm{ff}$ ). But this positive effect could also have been produced by the dilemma discussions which took place during the project.

Bottom line: In order to develop moral-democratic competence people must have the opportunity to apply and perfect it. (Lind 2015; Schillinger 2013) Like physical strength moral competence can only grow by being used. However, for many people the learning opportunities are scarce in the family, schools, universities and public institutions (Lind 2016).

\section{Democratic Education by Means of Dilemma Discussions}

It is possible to promote democratic and moral competence effectively with the help of certain methods of dilemma discussion. This is not true of all forms of dilemma discussion, but it does apply to the original form, the so-called Blatt Method, and to its followup model. The original form of an effective dilemma discussion model was developed in the 1970s by Moshe Blatt and Lawrence Kohlberg at the University of Harvard in the USA (Blatt and Kohlberg 1975). A meta-analysis of around 140 experimental studies revealed 
- not only for pedagogical methods - an unusually high effect size for this method (Lind 2002). Since the DES project mentioned above it has been increasingly used in Germany in teacher training and political education (Oser \& Althof 1994; Lind \& Raschert 1987; Reinhard 1989, 2012).

In spite of its effectiveness the Blatt Method is no longer supported today by its originators. They even advise against its use. Kohlberg writes:

Our research results indicated the operation was a success in the sense that ordinary classroom teachers ... reproduced the Blatt effect without being elaborately trained ... However, while the intervention was a success, the patient died: that is, we went back a year later and found that not a single teacher continued to do moral discussion after the commitment to the research had ended, even though it did lead to a one-third stage change (Kohlberg 1985, 33; see also Leming 1995; Althof 2015).

But Kohlberg and his disciples, as the saying goes, have thrown out the baby with the bathwater. Their method had indisputable advantages over former methods. It was pioneering because for the first time it placed the student as a moral subject at the center of democratic education and because it did not simply interest young people in the external aspects of democratic institutions but encouraged their active participation in the solution of problems and conflicts and hence effectively promoted their capacity to think and discuss.

I believe that the acceptance of the method was negatively affected by the inadequate training of the teachers, the non-transparency of the impact assessment and the instruction to the teachers to pre-formulate arguments for the students which were exactly one „stage” above their own level of moral development (the so-called „plus 1 convention"). This instruction assumed that the teachers could access the moral level of their students and find exemplary moral arguments which fitted the situation. This in turn meant that the teacher had to be well acquainted with the Kohlberg theory of moral stages and could competently apply the elaborate interview procedure needed to access the moral level of the students. This costs a great deal of time and effort, although the pedagogical benefits were by no means evident to them. Some teachers may also have noticed that the instruction to formulate arguments for their students contradicted the declared aim of educating them to think autonomously. The „plus 1 convention” may have activated the so-called "mirror neurons" but not the front right part of the brain (the right dorso-lateral prefrontal cortex), This part of the brain, as Prehn (2013) has shown, is of importance for the solution of moral dilemmas. In order to develop moral autonomy people must learn to develop the arguments for their standpoints themselves instead of adopting the arguments of others.

We know today that every confrontation with arguments leads to a growth in moral competence provided that a person understands them and has time to weigh them up. „Authorized” arguments do not have a developmental effect. This evidently only comes from direct confrontation with the arguments of others, including fellow students. 
Walker (1983) demonstrated experimentally that counter-arguments have the same effect as "plus 1" arguments. Hence the „plus 1 convention” was not even necessary for the achievement of a learning effect in dilemma discussions. This knowledge prompted the development of the Konstanz Method of Dilemma Discussion, which also forms the basis for the Discussion Theater dealt with later in this paper.

\section{The Konstanz Method of Dilemma Discussion (KMDD)®}

The KMDD was developed for educational institutions in order to promote effectively and efficiently the ability of participants to solve problems and conflicts by means of reflection and discussion instead of resorting to violence, deceit or subjection to the leadership of others. It has been dealt with in detail elsewhere (Lind 2015, 2017; Reinicke 2017), and I will restrict myself here to the treatment of a few features in which it differs from the Blatt Method. Above all, the KMDD is oriented very much more on the students than on the teachers. It offers the participants more time and more incentives to reflect upon a dilemma story, to become aware of their own feelings, to express them in words, and to reach a shared understanding of the story they are discussing with others, including those who hold different opinions. The participants only discuss one dilemma story and have 90 minutes at their disposal. In the Blatt Method they have to take up a position on three or more dilemma stories in 45 minutes.

As in the Blatt Method a KMDD session opens with a theatrical act. The leader of the session tells a story in which a fictive protagonist has to take a decision. The story is formulated in as simple as language as possible and it assumes only knowledge that all the participants can be expected to possess. This ensures that no-one is excluded from the discussion because the story is too difficult to follow.

It is also a feature of the KMDD that a story is presented and not a "dilemma." As presenters we hope that the participants, like ourselves, will find a dilemma in the story which is worth discussing. But we cannot be sure that they will do so. A dilemma is not objectively present but lies in the eyes of the observer. It is, therefore, possible that the participants see no dilemma in the story, or even several which in their eyes involve conflicting moral principles. Consequently, before the opening of every discussion, the participants are given time to consider quietly for themselves whether or not the decision of the protagonist involves a difficult problem and what that problem is. They then have the opportunity to exchange their perceptions of the story and the emotions it arouses in them with the other members of the group. They then discover that even in apparently very simple cases the perceptions of the group members often differ widely.

In the KMDD the discussion stands in the foreground and not the solution of an ethical dilemma, as is the case in ethics lessons. The voting on the decision taken on the story only serves the purpose of getting a discussion going. The participants are then given the task of convincing their opponents of the rightness of their decision. 
For a variety of reasons this task is very challenging. Some participants find it difficult to vote for or against the decision of the protagonist and choose to abstain. It is an even greater challenge for some to articulate the arguments in favor of their own opinion. They have possibly never thought about such a case. Some also fear social consequence if they publicly take a stance on a delicate issue. And it is yet more difficult again for many people to discuss critically the arguments of their opponents, particularly when the group members are separated physically into differing opinion camps sitting opposite one another.

As a result the task triggers off more or less strong emotions among the majority of the participants. This is both inevitable and desired, as it gives them the opportunity to learn how to deal with their own feelings and those of others. But the level of emotional arousal is important. To enable learning the emotions should not be too strong. Consequently the KMDD is so designed that it does not trigger off excessively strong emotions which could give rise to concealed or open enmity: On the one hand fictive and not real persons are discussed in the KMDD and, on the other hand, the participants are required to observe a basic rule in the discussion phase: They are allowed to say everything they wish, but they may not make value judgments about people, whether present in the group or not. If the rule is violated the teacher reminds the group of the need to observe it by means of an agreed sign. This has, however, never been necessary in KMDD sessions. Their strength is evidently based on the silent desire of all people to speak openly with others about important issues without this leading to quarrels. The teacher keeps this desire alive in all participants by mentioning the rule and by their mere presence. To this end the teachers sits in a position where everyone can see them and listen attentively to the discussion.

But the KMDD teacher does not intervene in the discussion, as is the case in the Blatt Method. The discussion is not even moderated by the teacher but by the participants themselves by observing the second KMDD rule, the so-called "ping-pong rule:" The participants call upon each other to contribute to the discussion. A member of one group can only speak when called upon to do so by a member of the opposing group who has just spoken. In this way the right to speak shifts smoothly between the two groups.

It is remarkable that in these sessions the democratic principle of free and respectful speech has never been broken, particularly as the discussions often give rise to strong emotions among the participants. This is revealed in various ways, for example when the "ping-pong rule" is forgotten and other participants or the teacher have to remind the group of the need to observe it. It is not seldom the case that the participants continue the discussion long after the KMDD session has finished. This strengthens the positive effects of the KMDD: the longer the participants reflect and discuss the more their moral development is promoted and, presumably, the more the dendrites and synapses are stimulated in those parts of the brain which are of importance for the growth of moral competence.

A KMDD session is, not over, however, when the discussion has ended. If, in spite of 
all the precautions taken, concealed hostile feelings have arisen in the group these scarcely continue beyond the subsequent reconciliation phase. In this phase the participants are called upon to nominate arguments of the opposite side for an "Argument Oscar." Which was the best argument of the opposing side? In this way the participants realize that their arguments have often made a greater impression on the other side than seemed to be the case during the discussion, that their opponents were not so committed to their own position as they seemed to be and that some of the participants only ended up in one of the two opinion camps more or less "by chance."

Following upon this phase the participants vote for a second time on the decision of the protagonist. Only rarely do changes of voting occur. In view of the difficulty of the problems and a discussion lasting only 30 minutes this can hardly be expected.

At the end the participants are asked whether they enjoyed the session and whether they learned anything from it. The KMDD sessions are mostly enjoyed by all the participants. People enjoy having the opportunity to speak and to exchange their opinions with others instead of simply listening to the teacher. But they also report on strong learning effects and, in part, on strong shifts of judgment (an emotional rollercoaster, as one participant put it). They point out that, although the discussion has not changed the direction of their decision, it has altered its quality. Some are no longer so sure that their judgment is in accordance with their own principles and state of knowledge. Others, however, feel that the discussion has strengthened their judgment. Both developments are usually regarded as beneficial. Remarkably, many participants report that it was a new experience for them to participate in a debate on a difficult issue with people of opposing opinions without experiencing lack of sympathy, animosity or even open aggression. Consequently they had been afraid of discussing delicate topics with others. The KMDD sessions eliminated this fear.

\section{The Effectiveness of KMDD}

The subjective impression of the participants that they had learned a great deal was confirmed by the results of the evaluation of the KMDD with an objective test. The KMDD has been used for 20 years in educational institutions in Germany and abroad, among others in elementary schools from the third grade on, in secondary schools, vocational schools, universities, prisons, military academies and old people's homes. The effectiveness of the method has been measured on many of these occasions. To this end the participants are tested (anonymously) before and after a KMDD course. In contrast to the Blatt method they do not have to take part in an elaborate interview, but simply fill out the short Moral Competence Test (MCT). The MCT measures the ability of the participants to judge arguments on the basis of their moral quality instead of their opinion conformity, a competence which, as we have shown above, is essential for living together in a democratic society. 
The test consistently reveals a strong increase in moral competence of a degree hitherto not demonstrated by other methods of moral and democratic education. (Lind 2002 ,2015). A single session is sufficient to allow the moral competence of the participants to grow more strongly than can be observed even in good school lessons in a year (Lind 2002; 2015; Hemmerling 2014).

The effectiveness of the KMDD cannot be attributed to the method alone, but is also the result of the thorough training of the KMDD teachers and group leaders. Experiments have shown that without thorough training of the teachers the method remains ineffective (Lind 2015). KMDD teachers must be acquainted with the emotions the dilemma stories are meant to trigger off among the participants, and with the precautions taken to ensure that these emotions do not get out of control and lead to aggression or to undesirable after-effects such as nightmares. They have to learn what moral competence is, how to choose and change a story so that it is understood by all the participants, how it triggers off an awareness of a dilemma and leads to a controversial discussion in the group. They have to learn how to apply and evaluate the Moral Competence Test (MCT), how to interpret its results and many other factors. Above all they have to learn to control their body language which possibly conveys unintended messages to the participants. In order to protect their training the KMDD has been registered as a protected trademark in the EU and some other countries (among others Turkey, China, Switzerland and Columbia). Only certified KMDD teachers are allowed to use it. The thorough schooling has also led to a high level of acceptance of the method among the teachers who have been trained in it. KMDD teachers do not need any further motivation (Hemmerling 2014; Reinicke 2017).

\section{From the KMDD to the Discussion Theater}

The Discussion Theater (DT) is the public form of the KMDD. The only difference is that it is performed publicly and that those who run it must recruit the participants. As in every theater the Discussion Theater combines real issues with fictive protagonists. It begins, like the KMDD, with a dilemma story, follows a certain choreography (it consists of nine acts) and has pedagogical intentions. It is designed to promote enlightenment and to encourage the participants to think and act for themselves. But it deviates from the traditional forms of theater in some points: it is inclusive and democratic and does not involve teaching from above.

Inclusive: Like the KMDD the Discussion Theater enables all people to participate actively without any previous training and with only a slight command of the language. They do not have to understand the allusions, quotations and metaphors in which the messages of the traditional theater are coded and which, consequently, are a high barrier to understanding for many people.

Democratic: In the Discussion Theater there are no actors and no audience, only participants who debate difficult issues without quarreling. There is no script but (as in 
the KMDD) only a choreography with nine acts and two rules which provide a framework for controversial discussions. In contrast to the classical theater this framework gives the participants the time they need to take up thought-provoking impulses and to share their thoughts with others.

Without teaching from above: Discussion Theater wishes to teach, but not in the style of the classical "enlightenment" theater. Among other things it teaches what Heinrich Kleist called the "gradual construction of thoughts during speech," namely the articulation of personal feelings. It also teaches the participants how to use the arguments of their opponents effectively for the development of their own ideas. Discussion Theater makes no appeals („Have the courage to think!”) or provoke indignation, but offers an opportunity for free thinking and free communication of the kind which Jürgen Habermas (1984) has in mind. The conclusions to be drawn from this thinking and discussing are left to the participants themselves.

\title{
9. Is This Still Theatre?
}

Discussion Theater is theater, yet it is not traditional theater. This theater also claims to promote freedom, but it keeps the public in a state of dependence.

\begin{abstract}
Theater (from the ancient Greek tó $\theta \varepsilon \dot{\alpha} \alpha$ cov théatron, a place for viewing, from $\theta \varepsilon \sigma \theta \alpha$ เ theasthai, to behold) is the term for the scenic presentation of an inner or outer happening as an artistic communication between actors (presenters) and the public... A minimal formula for theater would be: A plays (B) and C watches him (and both have a consciousness of their role as actors and viewers.) This means above all: the theater requires a public. The public can partly influence a performance (approval and rejection)... Above all it is a branch of the arts and consequently free... (German Wikipedia, 13.4.2018)
\end{abstract}

This one-sidedness of traditional theater - artistic freedom on the stage but a general passivity of the public - reflects the authoritarian circumstances under which it arose, but no longer seems fitting in the context of democracy. In a democratic society freedom is hindered not so much by autocratic rulers as by the inability of many citizens to meet the demands made on them by life in a democratic society and by fear of freedom. If theater today wishes to defend freedom and communication it must, as the great Friedrich Schiller noted in his On the Aesthetic Education of Man, free the audience from its role as mere onlookers and give them the opportunity to participate in free communication.

New forms of the theater such as Jonathan Fox's Playback Theater and Augusto Boal's Theater of the Oppressed attempt to democratize the theater. They permit more participation of the audience, but in this theater too the communication remains onesided. The articulatory sovereignty of the theater makers remains untouched.

The theater courtroom of Ferdinand von Schirach (in „The Terrorist”) goes a step further. In his theater courtroom the author has the actors discuss the question whether 
it is legitimate to sacrifice the lives of several hundred people in order to save the lives of several thousands and then lets the audience vote on the issue. They are not called upon to judge a person actually accused of a crime, but to make a judgment on a real institution - our constitution. A large majority of the audience regularly decides against our democratic basic values. "The dignity of man is inviolable" is the core statement of our Basic Law and of the international Declaration of Human Rights. This was explicitly pointed out by the German Constitutional Court in its judgment of 6 February 2006, when it forbade the shooting down of a passenger airplane with the aim of preventing a possible terrorist attack. Whoever uses the killing of people in order to rescue others, the judges state in their decision, „treats them as mere objects.” They are thus denied the values people enjoy for their own sake. Schirach's stage courtroom thus induces most of the audience to vote against the most important basic principle of democracy, the dignity of human beings, and hence against their own constitutional rights.

Schirach's play is not only legally but also psychologically dubious. It demands from the audience an emotional - unconsidered and untested - judgment. The audience has no time to reflect and discuss; it cannot make use of its own capacity for thinking and discussing. The author presents the exchange of arguments on the stage but the audience is not allowed to participate actively in the debate. Schirach restricts the audience to their role as passive onlookers. In the dialogues written for the actors he thinks for the audience like parents for their children, teachers for their students, leaders for their followers. Representative thinking is not independent thinking. Autonomous thinking alone promotes the moral competence of the individual (Lind 2005). The author thus prepares the audience for the vote on a very difficult issue only apparently but not genuinely. It is unlikely that at the moment of voting the audience is fully aware of the complexity of the case and the consequences of their decision. If the author had given the audience the opportunity to reflect for themselves on the case and to discuss their opinions with others many of them would certainly have reached a different decision.

\section{We Need a New Form of Theatre}

Discussion Theater fulfills the development of Schiller's ideas on the educational effects of the theater, formulated after his preoccupation with Kant's philosophy of freedom, namely of the stage as a moral institution which "creates freedom for the intellectual faculties."

Unlike the classical theater, which endeavors to achieve a powerful effect on the audience, the DT and the KMDD offer an opportunity to develop one's own intellectual faculties. We once presented 11th grade students with a problematic situation similar to the one in Schirach's play. It dealt with the question: Is it permissible to torture a person suspected of being a member of a terrorist group, so that he will disclose the plans of his group? When asked to give a judgment immediately after hearing the story, almost 
all voted in favor of the torture. They mostly justified their decision by arguing that less weight should be accorded to the suffering of the tortured person that to the possible death of many people, which one hoped to prevent. After they had been given time to think about the issue and to discuss it with others of a different opinion they soon began to have doubts about their original opinion - without any intervention by the teacher. How much must be at stake to justify torture? In what situations or on the basis of what suspicions is torture permissible? How certain is it that the torture will be successful? Do tortured people really tell the truth? Can the suffering of the victims really be prevented in this way? At the end of this process a fair number of the original advocates of torture came to the conclusion that torture must be categorically forbidden. Often they did not even know that such a prohibition already exists.

When we feel forced to make a swift decision before having the opportunity to weigh up the pros and cons and to discuss the issue with others, we often make decisions which cannot be sustained in the face of our subsequent judgment of the case. We sometimes show strangers the way, although we do not know it ourselves. We willingly answer the questions of opinion pollsters on the quality of certain products, on the character of strangers or the performance of politicians, even though we have had no opportunity to form a judgment. Only few of us pause for thought in such moments like the wise philosopher Socrates, who is reported to have said: "I know that I know nothing."

Populists gladly make use of this weakness. They know that we can be led to make quick judgments, if we do not have the opportunity to reflect on their simple slogans or to discuss them with others. Of course they are above all successful among people who find difficult to reflect and discuss and consequently prefer to adopt the opinion of others rather than running the risk that their own ideas will meet with incomprehension, derision or malice.

It is, therefore, important for the quality of democratic opinion formation that each individual not only has the right to express his/her opinion, but also the right to form that opinion. Discussion Theater makes a contribution here by giving the participants an opportunity to think for themselves and to discuss with others. As Lessing, Schiller and Brecht demanded, democracy needs a theater which educates. But for this not only its goals but also its methods must be democratic. Democracy needs a theater which does not treat people as onlookers but as participants, a theater that does not impart values and solutions of value conflicts but strengthens the ability of the participants to cope with their own moral values and with the conflicts which often inevitably result from them.

Discussion-Theater promotes moral democratic competence among all the participants and not just among the culturally well-educated. Like a drama it triggers off emotions but only to a certain degree, so that thinking and communicating are stimulated and sustained. Too little stimulus puts the audience to sleep, but too much prevents thinking and learning. Discussion Theater provides food for thought, but also the time and the place for thinking, for the articulation of personal feelings and the clarification of 
problems. It does not leave the participants in the passive role of onlookers but calls upon them to articulate their own opinions, to give reasons for them and to find arguments to convince others of their rightness. Nor is it mere role playing. It shows the participants that free, productive discussion is not only an ideal but is also possible. Many participants experience for the first time, as they say, that it is possible to discuss problems and conflicts with and against one another respectfully, that is to say without becoming "personal," as they have often found it to be the case in everyday life.

However, Discussion Theater is not pedagogical theater, although it can be carried out with and for children (from the age of around 8 years old). It is not a therapy, although it has therapeutic effects. It is not role-playing, although it enjoys high entertainment value. It is not a resocialization program, although it has already been implemented with great success in prisons (Hemmerling 2014). And it is not a means for the realization of political goals, although it strengthens reason and hence also democracy. It offers no solutions from above but promotes the ability of the participants to find on their own and with other people. It is not theater for oppressed people, but for people who are afraid of freedom and reject democracy because of this fear.

The previous stage productions - in an educational center and an old people's home in Konstanz, at a meeting of citizens' initiatives in Mexico and, most recently, several performances in the Dresden Church of Our Lady - were all a success. Sometimes we had to turn away potential participants because Discussion Theater, for acoustic reasons, can only accommodate about 50 participants. By celebrating democracy as a way of life Discussion Theater evidently fosters the enjoyment of democratic life. For the participants democracy is not an empty phrase or a risk; it is experienced as a personal gain.

\section{Epilogue I}

The following feedback from participants has been written down, partly from memory, after the staging of the Discussion Theater on March 7, 2018 in the Dresden Church of Our Lady:

„Thank you for the wonderful Discussion Theater yesterday. I have told my students about it and could scarcely control my enthusiasm. This discussion was so substantial, so many-sided, so intensive and enriching for me. I would go so far as to say that anyone who wasn't there really missed something great."

„I had really come up with many arguments about the story, but it surprised me that there were so many more."

„It was so agreeable to think calmly about my own standpoint. Nobody put me under pressure."

„The discussion was unbelievably intensive, free from notions of above and below, left or right. One could freely discuss the problems of both protagonists."

„By one of the arguments of the opposite side I was on the point of standing up 
and changing sides. That was powerful stuff."

„I liked the method of calling upon someone from the opposite side to contribute to the discussion. It expressed respect for one's opponent."

„This should be done much more often.”

\section{Epilogue II}

After a KMDD session a journalist who was present asked a 10-year old participant: "Just before, you had to deal with arguments which were contrary to your own opinion. Wasn't that waste of time?" Her answer after a short pause for thought: "No it wasn't. It encouraged me to think over my own arguments to see whether they were right."

\section{References}

Althof W. 2015. "Just Community Sources and Transformations: A Conceptual

Archeology of Kohlberg's Approach to Moral and Democratic Education," in B.

Zizek, D. Garz \& E. Nowak (Eds.), Kohlberg Revisited. Amsterdam: Sense Publishers (51-90).

Brecht B. 1963. „Das epische Theater, in idem, Schriften zum Theater 3. Frankfurt am Main: Suhrkamp.

Habermas J. 1984. The Theory of Communicative Action. Boston, MA: Beacon Press. Hemmerling K. 2014. Morality Behind Bars. Frankfurt am Main: Peter Lang.

Inglehart R. 2003. "How Solid Is Mass Support for Democracy. And How Can We Measure It?" Political Science \& Politics 36(1):51-7.

Jefferson Th. 1940. Letters, arranged by W. Whitman. Wisconsin: Eau Claire.

Kohlberg L. \& Candee D. 1984. "The Relationship of Moral Judgment to Moral Action," in L. Kohlberg (Ed.), Essays on Moral Development, Vol. II, The Psychology of Moral Development. San Francisco: Harper \& Row (498-582).

Kohlberg L. 1985. "The Just Community Approach to Moral Education in Theory and Practice," in W. M. Berkowitz \& F. Oser (Eds.), Moral Education: Theory and Application. Hillsdale, NJ: Erlbaum (27-87).

Leming J. S. 1995. "Reflections on Thirty Years of Moral Education Research." Moral Education Forum 20:1-9.

Lessing G. E. 1780. Die Erziehung des Menschengeschlechts [The education of the human race.]* 
Lind G. 1998. „Gewalt und Krieg als niedrigste Stufe der Konfliktbewältigung“ [Violence and war as the lowest stage of conflict resolution,] in W. Kempf \& I. SchmidtRegener (Eds.), Krieg. Nationalismus, Rassismus und die Medien. Münster: LITVerlag (273-82).

Lind G. 2002. Ist Moral lehrbar? Ergebnisse der modernen moralpsychologischen Forschung. 2nd revised edition. Berlin: Logos-Verlag.

Lind G. 2006. „Perspektive Moralisches und demokratisches Lernen,“ in A. Fritz, R. Klupsch-Sahlmann \& G. Ricken (Eds.), Handbuch Kindheit und Schule. Neue Kindheit, neues Lernen, neuer Unterricht. Weinheim: Beltz (296-309).

Lind G. 2016. How to Teach Morality. Promoting Deliberation and Discussion. Reducing Violence and Deceit. Berlin: Logos-Verlag. 4th Edition.

Lind G. 2017. Moralerziehung auf den Punkt gebracht. Schwalbach, Ts.: Debus Verlag. Lind G. \& Althof W. 1992. „Does the Just Community Experience Make a Difference? Evaluation and Evidence of the Effect Size of the German Program," Moral Education Forum (19-28).

Lind G. \& Raschert J. (Eds.) 1987. Moralische Urteilsfähigkeit - Eine Auseinandersetzung mit Lawrence Kohlberg über Moral, Erziehung und Demokratie. Weinheim: Beltz.

McFaul M. 2004. “Democracy Promotion As a World Value." The Washington Quarterly 28(1):147-63.

Oser F. \& Althof W. 1994. Moralische Selbstbestimmung. Modelle der Entwicklung und Erziehung im Wertebereich. Stuttgart: Klett-Cotta.

Nowak E., Schrader D. \& Zizek B. (Eds.). 2013. Educating Competencies for Democracy. Frankfurt am Main - New York - Bern: Peter Lang.

Prehn K. 2013. “Moral Judgment Competence: A Re-Evaluation of the Dual-Aspect Theory Based On Recent Neuroscientific Research," in E. Nowak, D. Schrader \& B. Zizek (Eds.), Educating Competencies for Democracy (9-22)

Reinhardt S. 1992. „Schule und Unterricht als Bedingungen von Demokratie-Lernen: Formen politischer Streitkultur als Bildungsaufgabe." Politische Bildung 2/92:3346.

Reinhardt S. 2012. Politikdidaktik. Praxishandbuch für die Sekundarstufe I und II. Berlin: Cornelsen.

Reinicke M. 2017. Moral 4.0, eine Aufgabe der Schule? Selbstverlag, www.martinareinicke.de

Schiller F. 1784. „Die Schaubühne als eine moralische Anstalt betrachtet“ [The stage considered as a moral institution.]

Schiller F. 1793-95. Über die ästhetische Erziehung des Menschen, in einer Reihe von Briefen [On the aesthetic education of man, in a series of letters.] ${ }^{*}$

Schillinger M. 2013. "Verifying the Dual-Aspect Theory: A Cross-Cultural Study On Learning Environment and Moral Judgment Competence," in E. Nowak, D. Schrader, \& B. Zizek (Eds.), Educating Competencies for Democracy (23-46). 
Sen A. 1999. “Democracy As a Universal Value." Journal of Democracy 10(3):3-17.

Sen A. 2009. The Idea of Justice. Cambridge, MA: Harvard University Press.

Tocqueville A. de 1976. Über die Demokratie in Amerika. München: Deutscher Taschenbuchverlag (first published 1835).

Walker L. J. 1983. "Sources of Cognitive Conflict for Stage Transition in Moral Development." Developmental Psychology 19:103-10.

Wilkinson R. \& Pickett K. 2010. The Spirit Level. Why Equality Is Better for Everyone. London: Penguin Books.

*Original texts from Gutenberg-Project of Spiegel publisher: http://gutenberg.spiegel.de/ 
Georg Lind (Konstanz)

\title{
Discussion Theater. A Method of Democratic Education
}

\begin{abstract}
Democracy is bound to fail if its citizens lack opportunities to develop their moral-democratic competence, that is, their ability to solve conflicts through thinking and discussion, instead of through violence, deceit or bowing down to others. The concept of Discussion Theatre has been designed to provide such an learning opportunity. In contrast to traditional theatre, there is no above and below, no division between actors and listeners - all are participants. The Discussion Theatre is the "public" version of the Konstanz Method of Dilemma Discussion (KMDD), which is been successfully used in institutions of education in many countries for over two decades.
\end{abstract}

Keywords: Democracy; education; moral competence; democratic competence; learning opportunities; KMDD; theatre; Schiller; Kohlberg; dilemma discussion.

Ethics in Progress (ISSN 2084-9257). Vol. 10 (2019). No. 1, Art. \#3, pp. 23-40.

Creative Commons BY-SA 4.0

Doi:10.14746/eip.2019.1.3 